\title{
Reading Comprehension Difficulties Among EFL Learners in Higher Learning Institutions
}

\author{
Hamza Al-Jarrah ${ }^{1} \&$ Nur Salina Binti Ismail ${ }^{1}$ \\ ${ }^{1}$ Faculty of Languages and Communication, Universiti Sultan Zainal Abidin, Terengganu, Malaysia. \\ Correspondence: Hamza Al-Jarrah, Faculty of Languages and Communication, Universiti Sultan Zainal Abidin, \\ 21300 Kuala Nerus, Terengganu, Malaysia. E-mail: Jarrah.hamza@yahoo.com
}

Received: May 23, 2018 Accepted: June 20, 2018 Online Published: November 27, 2018

doi:10.5539/ijel.v8n7p32 URL: https://doi.org/10.5539/ijel.v8n7p32

\begin{abstract}
One of the most significant problems faced by instructors is reading deficiency in English texts among the university students, which reflects the students' poor academic performance. It is assumed that learners who are unable to read and comprehend face many challenges during their studies and after graduation. This study aims to investigate reading comprehensions difficulties among EFL learners in higher learning institutions. The study employed quantitative method, 100 out of 281 Arab students of Universiti Sultan Zainal Abidin (UniSZA) and Universiti Malaysia Terengganu (UMT) were selected to participate in responding to the questions. Cross tabulation was used to analyze data from the test. Findings from the test indicated that the major difficulty faced by the Arab EFL learners is inability to recognize the types of text. This study concludes that the reading comprehension difficulties faced by Arab EFL learners in the selected institutions could affect their English language proficiency and academic performance. To find solutions to these difficulties, there is a need for shared efforts of English language teachers, instruction policy makers, public and private bodies responsible for educational policy learning and implementation, and the EFL learners.
\end{abstract}

Keywords: reading difficulties, EFL learners, comprehension, higher institutions

\section{Introduction}

\subsection{Importance of Reading}

English language skills are essential in attaining proficiency. These skills are either receptive or productive skills. Receptive skills involve reading and listening while productive skills consist of writing and speaking. Learners acquire receptive skills by receiving the language from oral or written material. In this case, learners decode the meaning to comprehend the receptive material. The importance of reading as a language skill can never be underestimated. It is one of the essential means through which information can be obtained especially for educational purposes. Reading serves as one of the most commonly utilized language proficiency skills across the globe. In addition, lack of reading ability results in poor academic performance among students. They also face various challenges outside the academic environment due to reading deficiency (Mundhe, 2015).

Learners who do not understand reading material cannot enjoy reading. Along with that, lack of understanding might be as a result of insufficient knowledge of vocabulary. This indicates that there is a strong correlation between reading comprehension and vocabulary knowledge. Therefore, EFL learners must acquire adequate knowledge of vocabulary to comprehend text. EFL students who developed a habit of dislike for the foreign language tend to have many difficulties in understanding reading materials related to the language. In addition, prior knowledge (schemata) helps learners to comprehend reading materials and construct meaning (Nozen et al., 2017; Vacca, 2002). In this regard, EFL learners who fail to connect their previous knowledge and predict the possible meaning of the text can face difficulties in understanding the text. This might be due to lack of in-depth knowledge of English derivation. Nezami (2012), the most noticeable issues faced by the teachers today is insufficiency in reading comprehension among students of higher institutions of learning. This deficiency might affect their academic performance.

A great number of students without sufficient vocabulary knowledge or effective learning strategies mostly face reading comprehension difficulties (Nor \& Rashid, 2018). They mostly encounter a series of continued failure during their studies due to bad experiences they had from the beginning (Hart \& Risley, 2003). This connection 
seems logical since students need high level of vocabulary in order to comprehend reading materials. Researchers pointed out that the degree of learners' vocabulary knowledge, prior knowledge, and grammatical knowledge are some of the significant difficulties influencing the reading comprehension (Koda, 2007).Nergis (2013) posited that deepness of vocabulary knowledge, syntactic consciousness and metacognitive recognition are some of the important factors influencing the reading comprehension.

Other studies have shown that grammatical knowledge plays a vital role in reading comprehension (Mehrpour \& Rahimi, 2010; Mecartty, 2000; Zhang, 2012). In addition, Shiotsu, and Weir (2007) stated that the learner's level of syntactic knowledge plays a role in their understanding of reading materials. In other words, learners with insufficient knowledge might not be able to achieve a higher level of reading ability. Therefore, readers need L2 syntactic knowledge to integrate their background knowledge and word's meaning (Koda, 2005).

Based on the condition highlighted, this study aims to examine reading comprehension difficulties among EFL learners, particularly Arab students in Universiti Sultan Zainal Abidin and Universiti Malaysia Terengganu. The study is expected to provide valid conclusion that can help in understanding and providing possible solutions to the problem.

\subsection{Reading Comprehension Difficulties}

Many studies investigated reading comprehension difficulties among students. Chawwang, (2008) investigated English reading problems among Thai EFL learners. The study found that most of the students face difficulties in reading English texts. Inadequate vocabulary knowledge was recognized as one of the main issues (Gunning, 2002). Vocabulary knowledge plays an important role in understanding complex reading materials such as textbooks, particularly those containing technical expressions (Carlisle, 2000; Qian, 2002). This is because students with poor vocabulary knowledge face difficulties in understanding technical words such as superordinate, synonyms, antonyms, or words with multiple connotations (Nuttall, 2000; Carlisle, 2000; Vilenius-Tuohimaa, Aunola, \& Nurmi, 2008).

Text complexity influences reading comprehension. Meaning that, learners' fluency in language enables them to have more in-depth understanding of text. Hence, oral ability is prominent when it comes to recognize how skilled a reader can be since students acquire new vocabulary through listening. Having adequate vocabulary helps students in clarifying the strange words by relating them with the context in which they are used (Dennis, 2008).

Another problem facing EFL learners is ability to understand complex sentences in reading comprehension. Complex sentences are sentences that consist of several clauses, and at times contain conjunctions such as although, because, furthermore, and however (Scott, 2009). Other causes of difficulties in reading comprehension among EFL learners include coordinating conjunctions, prepositional phrases, participial phrases, and nominalizations. They cause a lot of difficulties in reading comprehension because they make the writings more complex and difficult to comprehend (Nuttall, 2000). However, Trehearne and Doctorow (2005) further identified other factors such as useful learning methods, reading habits, text form, and effective reading comprehension strategies.

Other factors influencing reading comprehension skills include exposure to the text organization and concentration (Perfetti, Landi, \& Oakhill, 2004; Meniado, 2016).According to Davoudi and Yousefi (2015), causes of difficulties in reading for many learners include environmental, instructional, and biological sources. The author argued that for one reason or another, learners who face reading difficulties have comprehension problems, and for some students, these comprehension problems could be due to imprecise or ineffective word recognition and decoding methods. The environmental circumstances influence the learners' reading comprehension. They may have many difficulties in understanding reading materials in a disorganized environment. However, those in a peaceful and controlled environment may have more effective reading ability. Students in an insecure domicile find it difficult to concentrate on their reading. But if they find themselves in safe environments, efficiency in their reading comprehension tends to improve. It is proven that learners lose focus in reading comprehension in a noisy place such as areas with high volume of televisions or radios (Dennis, 2008).

For others, comprehension difficulties could be due to deficiencies in language or cognitive processes. Also motivation and concentration are factors that might influence comprehension, since particular group of readers could understand simple words or expressions, but face difficulty in understanding longer sentences (Laing \& Kamhi, 2002; Anmarkrud \& Bråten, 2009). 
Some studies confirmed that reading comprehension is related to learners' ability to identify and correct syntactic errors. Subject-verb agreement is a typical example of syntax. It explains the relationship between words (subjects and verbs) in sentence formation (Franck et al., 2007). For instance, Cain (2007) confirmed the relationship between syntactic awareness and reading comprehension. According to the author, this relationship was mediated by vocabulary, grammatical knowledge, and memory. Shiotsu and Weir (2007) also found that syntactic knowledge is superior over vocabulary knowledge in predicting performance on a reading comprehension assessment. Background knowledge is an important factor in reading comprehension (Zhang \& Shanshan, 2011). It is one of the significant factors influencing reading comprehension scores (McNeil, 2011). Given that, several studies established the significance of background knowledge in reading comprehension in many circumstances (Nassaji, 2002; Chou, 2011; Zhang \& Shanshan, 2011). Learners require background knowledge to develop global understanding and fill relative gaps within the write up. In this situation, if the learners' background knowledge is inadequate and deficient, their readings will contradict the information within the writing (Zhang \& Shanshan, 2011).

According to Lerner (2000), learners with good background in reading tend to read more and improve their proficiency compared to those with poor background in reading. In a similar vein, Lyon (2000) posited that learning starts prior to formal school enrolment, and that those who have motivating learning experiences from birth have an advantage in understanding reading purposes, awareness learning conceptions, and vocabulary development. There is possibility for children to face reading failure when entering elementary schools without early reading experiences (Lyon, 2000).

Background knowledge is an important factor in achieving reading comprehension ability. It plays a dynamic role in comprehension of text, and its absence can negatively influence reading comprehension (Aebersold \& Field, 1997; Hudson, 2007; Vacca \& Vacca, 2008). According to the findings of Nguyen (2007), learners who had prior knowledge comprehend reading materials easily. However, learners who are not exposed to diverse strange reading materials have many difficulties in understanding them, and they need to read several times to comprehend the texts.

Recent studies on reading comprehension demonstrated that numerous factors obstruct student's reading comprehension (Torgeson, 2002; National Reading Panel, 2000). For instance, Karen's (2015) study focused on factors influencing reading comprehension amongst disabled secondary students. The study found that one of the most significant factors is phonemic knowledge, which refers to ability to process the distinct sounds of letters required for word recognition. For example, a reader should be able to differentiate the three individual phonemes in the word 'bug', and then compose the sounds to pronounce the word. Poor knowledge of phonemics and working memory restrict student's ability to read fluently, which is associated with reading comprehension difficulties (Torgeson, 2002; National Reading Panel, 2000).

Another factor that affects students' reading ability is poor working memory (Alloway et al., 2009; Swanson et al., 2009). Working memory enables readers to store information in short-term memory while engaging in cognitive tasks. It is therefore possible for a learner to read and activate previous information about a subject or determine the meaning of a word from context while recalling what has been read. Disabled learners mostly have low working memory abilities, which can influence their reading comprehension. Swanson et al. (2009) asserted that learners who struggle to read are unable to recall orderly information directly associated with processes of phonological retention. Retention of phonological information is necessary in learning. Also direct association between learning, working memory, and academic performance exists (Alloway, 2009)

During reading comprehension, several cognitive processes are involved. Good vocabulary skills are necessary to enable learners read competently (Taylor et al., 2009). But unfortunately, learners mostly avoid reading as they struggle to read. Additionally, Cain and Oakhill (2011) found that reading influences vocabulary improvement, since vocabulary skills of learners who do not read regularly are negatively influenced. Research evidently discovers that depth of vocabulary knowledge affects reading comprehension more than any other factor (Baleghizadeh \& Golbin, 2010; Moghadam, Zainal, \& Ghaderpour, 2012; Anjomshoa \& Zamanian, 2014; Mohammadi \& Afshar, 2016).

Also working memory level affects reading comprehension. This implies that human memory is considered a significant cognitive factor in reading comprehension. It enables learners to have better understanding of texts (Kintsch \& Kintsch, 2005; Chrysochoou, Bablekou, \& Tsigilis, 2011; Nouwens, Groen, \& Verhoeven, 2017). According to Vazalwar (2011), anxiety influences reading comprehension negatively. The study found that anxiety is negatively associated with students' reading comprehension. This means that standard level of anxiety would have a positive influence on reading comprehension. In fact, anxiety is a feeling related to fear, and it 
influences reading comprehension. Other studies (Wu, 2011; Jafarigohar \& Behrooznia, 2012) also established that anxiety is negatively associated with reading comprehension. Grills-Taquechel et al. (2012) asserted that poorer academic performance may occur if learners are distracted by their anxious thought such as being panic and behaviors like shaking hands. Other factors related to anxiety in reading comprehension include homework, class work, and examination conditions. These conditions force students to read beyond reading for pleasure. Certain learners respond to these conditions positively while others are overcome by the burden to read under pressure. Therefore, learners who involve in this kind of anxiety are likely to have poor reading comprehension (Dennis, 2008).

Some studies suggest that grammar Knowledge have a prominent role in reading comprehension. The level of grammar knowledge among EFL learners influences their comprehension of text. Learners with inadequate knowledge of grammar tend to have difficulties in reading comprehension. Therefore, EFL learners require grammar knowledge to comprehend meaning of expressions in passages (Koda, 2005). Studies indicated that there is a significant relationship between grammar knowledge and reading comprehension. EFL learners' grammar level is a vital element in unstinting written document. Similarly, Haarman (1988) found that there were strong associations between grammatical knowledge and reading comprehension. Bernhardt (2000) also noted that EFL learners' reading ability relatively depends on their grammatical knowledge.

It is evident from the foregoing review that factors such as second language learners' vocabulary, cognitive ability, text complexity, nature of environment, background knowledge, and prior knowledge determine their level of reading comprehension. It is also believed that once the learners acquire enough vocabulary, their language proficiency will improve. Hence, this study aims to examine reading comprehension difficulties among Arab EFL learners.

\section{Method}

This study employs quantitative method, in which test techniques is used to collect data from 100 EFL learners of Universiti Sultan Zainal Abidin (UniSZA) and Universiti Malaysia Terengganu (UMT) Quantitative research methods deal with numerical data in a systematic way of investigating a particular phenomenon. It is used to answer questions on the relationships among measurable variables with an intention to explain, predict and control phenomena (Leedy, 1993). In this regard, researchers typically select the quantitative approach to respond to the research questions requiring numerical data. Therefore, this study utilizes test as numerical data to examine the difficulties faced by EFL learners.

According to Creswell (2011), quantitative research consists of strategies of inquiry, and collects data on predetermined instruments that yield statistical results. Short paragraph entitled what are the duties of a student is chosen to identify the students' common reading comprehension difficulties. A test entails 11 questions related to reading comprehension difficulties in general were designed. The questions were modified to become compatible with the research objective and research problem of the study. The overall aim of this study is to examine reading comprehension difficulties amongst EFL learners in Universiti Sultan Zainal Abidin and Universiti Malaysia Terengganu.

\subsection{Sampling Technique}

Participants in this study was selected using probability sampling, in which simple random sampling is used. The researcher chooses the EFL learners at random, where the test is administered to any student at reach. In simple random sampling, each member of the population under study has an equal chance of being selected, and the probability of a member of the population being selected is unaffected by the selection of other members of the population. The method involves selecting at random from a list of the population subjects for the sample to allow each element from the population have equal chance of being selected and included in the study (Cohen et al., 2007). The population in the quantitative phase of this study consists of Arab postgraduate students from different faculties of Universiti Sultan Zainal Abidin and Universiti Malaysia Terengganu.

\subsection{Participants}

100 out of 281 Arab students of UniSZA and UMT are selected to participate in responding to the questions. Out of the total population, 213 Arab students are from UniSZA and 68 are from UMT. This figure is based on email confirmation from UMT and students official bulletin from UniSZA. This sample was based on Gay and Diehl (1992) proposal that $20 \%$ of the target population is sufficient for analysis.

\subsection{Method of Data Analysis}

The test is analyzed using cross tabulation, where IBM SPSS is used as a tool for analysis. It is one of the most useful analytical tools used in analyzing categorical data and a wealth of information about relationship among 
the variables (Wildemuth, 2016). The data obtained from the test are analyzed based on answers provided by the students.

\section{Results}

This study is set to investigate the difficulties faced by Arab EFL learners in reading comprehending to address this objective, several issues related to reading comprehension are tested in order to find out the reading comprehension difficulties faced by the EFL learners. These issues are vocabulary knowledge, prior knowledge, grammatical knowledge, meaning of phrase, word difficulty, syntax, environmental factors, reading strategies, anxiety, attention, and text structure. The following table presents the findings related to the difficulties faced by Arab EFL learners in reading comprehension particularly at UniSZA and UMT.

Table 1. Reading comprehension difficulties

\begin{tabular}{llllll}
\hline SN & Difficulty & \multicolumn{2}{l}{ Response } & \multicolumn{2}{l}{ Wrong } \\
\cline { 3 - 6 } & & \multicolumn{2}{l}{ Correct } & \multicolumn{3}{l}{} \\
\cline { 3 - 6 } & & F & $\%$ & F & $\%$ \\
\hline 1 & Vocabulary knowledge & 53 & 55.8 & 42 & 44.2 \\
2 & Prior knowledge & 33 & 34.7 & 62 & 65.3 \\
3 & Grammatical knowledge & 45 & 47.4 & 50 & 52.6 \\
4 & Word difficulties & 45 & 47.4 & 50 & 52.6 \\
5 & Lack of attention & 42 & 44.2 & 53 & 55.8 \\
6 & Syntactic error & 54 & 56.8 & 41 & 43.2 \\
7 & Meaning of phrase & 55 & 57.9 & 40 & 42.1 \\
8 & Text structure & 25 & 26.3 & 70 & 73.7 \\
\hline
\end{tabular}

Table 1 shows that $55.8 \%$ of the respondents are able to answer the questions on vocabulary knowledge correctly while $44.2 \%$ are unable to respond correctly. Regarding prior knowledge, which helps learners to comprehend reading materials and construct meaning, $34.7 \%$ answer the questions correctly. About $65.3 \%$ of the respondents do not respond to the questions on prior knowledge correctly. In addition, $47.4 \%$ of the respondents are able to answer the questions on grammatical knowledge correctly while $52.6 \%$ are not able to answer the questions. Forty-seven percent $(47.4 \%)$ have the ability to answer the questions related to difficulties in word difficulty while $52.6 \%$ are unable to answer the questions.

Regarding attention to the text, $44.2 \%$ of the respondents are able to respond to the questions correctly while $55.8 \%$ are unable to answer the questions correctly. A total of 56.8\% respondents are able to correct syntactic errors while $43.2 \%$ responded wrongly to the questions on syntax. About $57.9 \%$ of the respondents are able to recognize meaning of phrases in sentence while $42.1 \%$ do not provide correct meaning of the phrases in sentence. Only $26.3 \%$ of the respondents are able to identify the structure of the text given to them while $73.7 \%$ are unable to identify the type of text structure they read during the test. These findings indicate that the major difficulty faced by the Arab EFL learners examined in this study is lack of ability to recognize the types of text or text structure they read. According to Trehearne and Doctorow (2005), text form is one of the factors influencing EFL Learners' reading comprehension. For example, more main ideas might be recalled for narrative text than expository text as revealed in a study conducted by Yoshida (2012).

Apart from determining the reading comprehension difficulties, this study also examines the contributing factors that lead to reading comprehension difficulties faced by EFL learners. The following table presents the kinds of anxiety experienced by the respondents while reading text materials.

Table 2. EFL Learners' anxiety

\begin{tabular}{lll}
\hline SN & Type of anxiety & Response (\%) \\
\hline 1 & Panic & $13.7 \%$ \\
2 & Nauseated & $13.7 \%$ \\
3 & Shaky hand & $15.8 \%$ \\
4 & Blank-minded & $27.4 \%$ \\
5 & Trouble writing answers & $41.1 \%$ \\
6 & All of the above & $9.50 \%$ \\
7 & None of the above & $46.3 \%$ \\
\hline
\end{tabular}


Table 2 indicates that $13.7 \%$ of the respondents feel panic or nauseated while reading English comprehension text respectively. Additionally, $15.8 \%$ of the respondents indicate that they feel shaky hand while reading the text while up to $27.4 \%$ feel blank minded. Up to $41.1 \%$ of the respondents indicate that they feel trouble writing answers regarding comprehension text. Only $9.50 \%$ of the respondents state that they have all the aforementioned anxiety problems while reading the text while up to $46.3 \%$ believed that they do not have any of the aforementioned difficulties. These findings show that the major difficulty faced by the Arab EFL learners related to anxiety is feeling trouble writing answers. Based on the data status, it can be seen that feeling panic, nauseated, or shaky hand are rarely found amongst the EFL learners examined in this study. Further to this, Grills-Taquechel et al. (2012) asserted that poorer academic performance may occur if learners are distracted by their anxious thought such as being panic and behaviors like shaking hands. Vazalwar (2011) found that anxiety is negatively associated with students' reading comprehension. The following table depicts the kinds of environmental factors affecting the EFL learners reading comprehension.

Table 3. Environmental factors

\begin{tabular}{lll}
\hline SN & Factors & Response (\%) \\
\hline 1 & Noise in the environment & $25.3 \%$ \\
2 & Unfavorable weather & $17.5 \%$ \\
3 & All of the above & $13.7 \%$ \\
4 & None of the above & $68.4 \%$ \\
\hline
\end{tabular}

As indicated in table 3, 25.3\% of the respondents state that noisy environment affects their reading comprehension. Further to this, $(17.5 \%)$ of the respondents indicate that unfavorable weather negatively affects their reading comprehension. This means that majority of the respondents in this study cannot fully understand English reading materials in a noisy environment. This finding is consistent with Davoudi and Yousefi (2015), who found that environmental factors such as noisy environment affect the learners' reading comprehension negatively. EFL learners may experience various difficulties while trying to comprehend reading materials in a disorganized environment. The following table describes the various strategies used by the EFL learners to comprehend English reading material.

Table 4. Reading strategies

\begin{tabular}{lll}
\hline SN & Strategies & Response (\%) \\
\hline 1 & Repeating the sentence several times & $52.6 \%$ \\
2 & Translating the meaning into my mother tongue & $60 \%$ \\
3 & Focusing on the parts I understand more & $52.6 \%$ \\
4 & All of the above & $30.5 \%$ \\
5 & None of the above & $17.9 \%$ \\
\hline
\end{tabular}

The respondents are asked to respond to questions on the various strategies they use when trying to understand written English materials. As shown in Table 4, 52.6\% of the respondents state that they employ the strategy of repeating the sentences contained in the passages several times until they understand the intended message. Sixty percent $(60 \%)$ of the respondents respond that they translate the meaning of the words or sentence into their mother tongue in order to understand the text. Meanwhile, $52.6 \%$ of the respondents state that they focus on the parts which they understand more in the passage. Understanding most familiar parts to them can help them in understanding the other parts of the reading material. About $30.5 \%$ of the respondents show that they use all of the aforementioned strategies while trying to understand the written English material. Only $17.9 \%$ of the respondents indicate that they do not use any of the strategies mentioned above.

This information indicates that the EFL learners examined in this study use more of the strategy of translating the meaning of word or sentence into their mother tongue than repeating sentence or focusing on certain parts which they understand more to help them understand the material. This finding indicates that reading strategies such as translating the meaning into mother tongues help students in understanding the reading material. This is in the line with the findings of Gilakjani and Sabouri (2016) that reading strategies can help EFL Learners to comprehend reading material. 


\section{Discussion}

This study examines reading comprehension difficulties among Arab EFL learners in higher institutions According to Nezami (2012), the most noticeable issues faced by the teachers today is insufficiency in reading comprehension among students of higher institutions of learning. This deficiency might affect their academic performance. Researchers pointed out that the degree of learners' vocabulary knowledge, prior knowledge, and grammatical knowledge are some of the significant factors influencing the reading comprehension (Koda, 2007; Nergis, 2013).

The objective of this study is to identify reading comprehension difficulties faced by the EFL learners. It was found that the major difficulty faced by the Arab EFL learners examined in this study is lack of ability to recognize the types of text or text structure they read. Other difficulties faced by the students are related to factors such as lack of prior knowledge, difficulties in word difficulties, and. lack of paying attention to the text, Moreover, Trehearne and Doctorow (2005) found that text form is one of the significant factors affecting reading comprehension. In line with this finding, some studies reveal that exposure to the text organization and reader's attention are amongst the factors influencing reading comprehension (Perfetti, Landi, \& Oakhill, 2004; Meniado 2016; Nergis, 2013). According to Nezami (2012), teachers face great challenges from reading comprehension among Arab university students.

\section{Conclusion}

This study used test to specifically investigate the difficulties faced by the EFL learners in reading comprehension. It is evident that the EFL learners faced several reading difficulties when they reading English texts The quantitative phase in this study reveals that the major difficulty faced by the Arab EFL learners is lack of ability to recognize the types of text or text structure they read, followed by lack of attention, word difficulty, and grammatical knowledge. It is also evident that the major difficulty faced by the Arab EFL learners related to anxiety is feeling trouble writing answers, and majority of them do not have anxiety problem. The respondents tend to comprehend reading materials more in a less noisy environment and favorable weather than when they find themselves reading in a noisy environment and unfavorable weather, and majority of them do not have problems with environmental factors. Additionally, the main strategy used by the EFL learners is translating the meaning of word or sentence into their mother tongue to help them understand the English material, and majority of them employ translation reading strategies, To find solutions to these difficulties, there is a need for shared efforts of English language teachers, instruction policy makers, public and private bodies responsible for educational policy learning and implementation, and the EFL learners.

\section{References}

Aebersold, J. A., \& Field, M. L. (1997). From Reader to Reading Teacher: Issues and Strategies for Second Language Classrooms. Cambridge, NY: Cambridge University Press.

Alloway, T. P., Gathercole, S. E, Kirkwood, H. J., \& Elliott, J. E. (2009). The cognitive and behavioural characteristics of children with low working memory. Child Development, 80(2), 606-621. https://doi.org/10.1111/j.1467-8624.2009.01282.x

Anjomshoa, L., \& Zamanian, M. (2014). The effect of vocabulary knowledge on reading comprehension of Iranian EFL learners in Kerman Azad University. International Journal on Studies in English Language and Literature (IJSELL), 2(5), 90-95.

Anmarkrud, Ø., \& Bråten, I. (2009). Motivation for reading comprehension. Learning and Individual Differences, 19(2), 252-256. https://doi.org/10.1016/j.lindif.2008.09.002

Baleghizadeh, S., \& Golbin, M. (2010). The effect of vocabulary size on reading comprehension of Iranian EFL learners. LiBRI. Linguistic and Literary Broad Research and Innovation, 1(2), 33-47.

Bernhardt, E. B. (2000). Second language reading as a case study of reading scholarship in the 20th century. In M. L. Kamil, P. D. Pearson, \& R. Barr (Eds.), Handbook of Reading Research (Vol. III, pp. 791-811). Mahwah, NJ: Lawrence Erlbaum Associates.

Cain, K. (2007). Syntactic awareness and reading ability: Is there any evidence for a special relationship?. Applied psycholinguistics, 28(4), 679-694. https://doi.org/10.1017/S0142716407070361

Cain, K., \& Oakhill, J. (2011). Matthew effects in young readers: Reading comprehension and reading experience aid vocabulary development. Journal of Learning Disabilities, 44(5), 431-443. https://doi.org/10.1177/0022219411410042 
Carlisle, J. F. (2000). Awareness of the structure and meaning of morphologically complex words: Impact on reading. Reading and writing, 12(3), 169-190. https://doi.org/10.1023/A:1008131926604

Chawwang, N. (2008). An Investigation of English Reading Problems of Thai 12 th-Grade Students in Nakhonratchasima Educational Regions 1, 2, 3, and 7 (Doctoral dissertation). Srinakharinwirot University, Thailand.

Chou, P. T. M. (2011). The Effects of Vocabulary Knowledge and Background Knowledge on Reading Comprehension of Taiwanese EFL Students. Electronic Journal of Foreign Language Teaching, 8(1), 108-115.

Chrysochoou, E., Bablekou, Z., \& Tsigilis, N. (2011). Working memory contributions to reading comprehension components in middle childhood children. The American journal of psychology, 124(3), 275-289. https://doi.org/10.5406/amerjpsyc.124.3.0275

Cohen, L., Lawrence, M., \& Keith, M. (2007). Research methods in education. New York: Routledge. https://doi.org/10.4324/9780203029053

Creswell, J. W., \& Plano Clark, V. L. (2011). Designing and conducting mixed methods research (2nd ed.). Thousand Oaks, CA: Sage Publications, Inc.

Davoudi, M., \&Yousefi, D. (2015). Comprehension Breakdown: A Review of Research on EFL Learners' Reading Difficulty and Problems. All rights reserved, 58(1), 22-31.

Dennis, D. V. (2008). Are Assessment Data Really Driving Middle School Reading Instruction? What we can learn from one student's experience. Journal of Adolescent and Adult Literacy, 51(7), 578-587. https://doi.org/10.1598/JAAL.51.7.5

Franck, J., Frauenfelder, U. H., \& Rizzi, L. (2007). A Syntactic Analysis of Interference in Subject-Verb Agreement. MIT working papers in linguistics, 1(53), 173-190.

Gay, L. R., \& Diehl, P. L. (1992). Research Methods for Business and Management. New York: Macmillan.

Gilakjani, A. P., \& Sabouri, N. B. (2016). A Study of Factors Affecting EFL Learners' Reading Comprehension Skill and the Strategies for Improvement. International Journal of English Linguistics, 6(5), 180-192. https://doi.org/10.5539/ijel.v6n5p180

Grills-Taquechel, A. E., Fletcher, J. M., Vaughn, S. R., \& Stuebing, K. K. (2012). Anxiety and reading difficulties in early elementary school: Evidence for unidirectional-or bi-directional relations?. Child Psychiatry \& Human Development, 43(1), 35-47. https://doi.org/10.1007/s10578-011-0246-1

Gunning, T. G. (2002). Assessing and correcting reading and writing difficulties. Boston: Division of Simon \& Schuster, Inc.

Haarman, L. (1988). Some considerations on the role of grammar in L2 reading. Studiitaliani di linguisticateoricaedapplicata, 17(1), 95-118.

Hart, B., \& Risley, T. R. (2003). The early catastrophe: The 30 million word gap by age 3. American educator, 27(1), 4-9.

Hudson, T. (2007). Teaching Second Language Reading. New York, NY: Oxford University Press.

Jafarigohar, M., \& Behrooznia, S. (2012). The effect of anxiety on reading comprehension among distance EFL learners. International Education Studies, 5(2), 159-174. https://doi.org/10.5539/ies.v5n2p159

Karen, S. L. (2015). Factors that affect reading comprehension of secondary students with disability (Doctoral dissertation). University of San Francisco, United States.

Kintsch, W., \& Kintsch, E. (2005). Comprehension. In S. Paris \& S. Stahl (Eds.), Children's Reading Comprehension and Assessment (pp. 71-92). Mahwah, NJ: Lawrence Erlbaum Associates.

Koda, K. (2005). Insights into second language reading: A cross-linguistic approach. Cambridge, UK: Cambridge University Press. https://doi.org/10.1017/CBO9781139524841

Koda, K. (2007). Reading Language Learning: Cross-Linguistic Constraints on Second Language Reading Development. Language Learning, 57(1), 1-44. https://doi.org/10.1111/0023-8333.101997010-i1

Laing, S., \& Kamhi, A. (2002). The use of think-aloud protocols to compare inferencing abilities in average and below-average readers. Journal of Learning Disabilities, 25(5), 437-448. https://doi.org/10.1177/00222194020350050401 
Leedy, P. D. (1993). Practical research: planning and design. New Jersey: Prentice-Hall.

Lerner, J. (2000). Learning Disabilities: Theory, Diagnosis and Teaching Strategies (8th ed.). Boston: Houghton Mifflin Company.

Lyon, G. R. (2000). Why some children have difficulties to learn to read. Retrieved from http://www.readingrockets.org/article/why-some-children-have-difficulties-learning-read

McNeil, L. (2011). Investigating the contributions of background knowledge and reading comprehension strategies to L2 reading comprehension: An exploratory study. Reading and Writing, 24(8), 883-902. https://doi.org/10.1007/s11145-010-9230-6

Mecartty, F. H. (2000). Lexical and grammatical knowledge in reading and listening comprehension by foreign language learners of Spanish. Applied Language Learning, 11(2), 323-348.

Mehrpour, S., \& Rahimi, M. (2010). The impact of general and specific vocabulary knowledge on reading and listening comprehension: A case of Iranian EFL learners. System, 38(2), 292-300. https://doi.org/10.1016/j.system.2010.01.004

Meniado, J. C. (2016). Metacognitive Reading Strategies, Motivation, and Reading Comprehension Performance of Saudi EFL Students. English Language Teaching, 9(3), 117-129. https://doi.org/10.5539/elt.v9n3p117

Moghadam, S. H., Zainal, Z., \& Ghaderpour, M. (2012). A review on the important role of vocabulary knowledge in reading comprehension performance. Procedia-Social and Behavioral Sciences, 66(1), 555-563. https://doi.org/10.1016/j.sbspro.2012.11.300

Mohammadi, S. M., \& Afshar, N. B. (2016). Vocabulary knowledge learning and reading comprehension performance: which one is superior-breadth or depth?. International Journal for 21st Century Education, 3(2), 5-14. https://doi.org/10.21071/ij21ce.v3i2.5850

Mundhe, G. B. (2015). Teaching Receptive and Productive Language Skills the Help of Techniques. Pune Research an International Journal in English, 1(2), 1-6.

Nassaji, H. (2002). Schema theory and knowledge-based processes in second language reading comprehension: a need for alternative perspectives. Language Learning, 52(2), 439-481. https://doi.org/10.1111/0023-8333.00189

National Reading Panel. (2000). Teaching children to read: An evidence-based assessment of the scientific research literature on reading and its implications for reading instruction [on-line]. Retrieved from http://www.nichd.nih.gov/publications/nrp/report.cfm

Nergis, A. (2013). Exploring the factors that affect reading comprehension of EAP learners. Journal of English for Academic Purposes, 12(1), 1-9. https://doi.org/10.1016/j.jeap.2012.09.001

Nezami, S. A. (2012). A critical study of comprehension strategies and general problems in reading skill faced by Arab EFL learners with special reference to Najran University in Saudi Arabia. International Journal Social Science and Education, 2(3), 306-316.

Nguyen, H. T. (2007). Educating Vietnamese American students. Multicultural Education, 15(1), 23-26.

Nor, N. M., \& Rashid, R. A. (2018). A review of theoretical perspectives on language learning and acquisition. Kasetsart Journal of Social Sciences, 39(1), 161-167. https://doi.org/10.1016/j.kjss.2017.12.012

Nouwens, S., Groen, M. A., \& Verhoeven, L. (2017). How working memory relates to children's reading comprehension: the importance of domain-specificity in storage and processing. Reading and Writing, 30(1), 105-120. https://doi.org/10.1007/s11145-016-9665-5

Nozen, S. Z., Kalajahi, S. A. R., Abdullah, A. N., \& Jabbarzadeh, H. (2017). An investigation of the impacts of teaching writing skill through extensive short story reading. Journal of Nusantara Studies, 2(1), 53-70. https://doi.org/10.24200/jonus.vol2iss1pp53-70

Nuttall, C. (2000). Teaching reading skills in a foreign language. Oxford: Macmillan.

Perfetti, C. A., Landi, N., \& Oakhill, J. (2004). The Acquisition of Reading Comprehension Skill. Retrieved from http://www.pitt.edu/ perfetti/PDF/The\%20Acquisition\%20of\%20Reading\%20Comprehension\%20Skill.pdf

Qian, D. D. (2002). Investigating the relationship between vocabulary knowledge and academic reading performance: An assessment perspective. Language learning, 52(3), 513-536. https://doi.org/10.1111/1467-9922.00193 
Shiotsu, T., \& Weir, C. J. (2007). The relative significance of syntactic knowledge and vocabulary breadth in the prediction of reading comprehension test performance. Language Testing, 24(1), 99-128. https://doi.org/10.1177/0265532207071513

Swanson, H. L., Zheng, X., \&Jerman, O. (2009). Working memory, short-term memory, and reading disabilities: A selective meta-analysis of the literature. Journal of Learning Disabilities, 42(3), 260-287. https://doi.org/10.1177/0022219409331958

Taylor, D. B., Mraz, M., Nichols, W. D., Rickelman, R. J., \& Wood, K. D. (2009).Using explicit instruction to promote vocabulary learning for struggling readers. Reading \& Writing Quarterly, 25(2-3), 205-220. https://doi.org/10.1080/10573560802683663

Torgeson, J. K. (2002). The Prevention of Reading Difficulties. Journal of School Psychology, 40(1), 7-26. https://doi.org/10.1016/S0022-4405(01)00092-9

Trehearne, M. P., \& Doctorow, R. (2005). Reading Comprehension: Strategies That Work. Comprehensive Literacy Resource: Grade 3-6 (Chapter 2). Retrieved from https://www.hand2mind.com/pdf/miriam/ch2_clr3_6.pdf

Vacca, R. T., \&Vacca, J. L. (2008). Content Area Reading: Literacy and Learning across the Curriculum (9th ed.). Boston, MA: Pearson.

Vacca, R.T. (2002). Making a Difference in Adolescents' School Lives: Visible and Invisible Aspects of Content Area Reading. In A. E. Farstrup \& S. J. Samuels (Eds.), Hillsdale, NJ: Lawrence Erlbaum Associates.

Vazalwar, C. H. (2011). Effect of Anxiety on Reading Comprehension in English. International Journal of Multidisciplinary Research, 1(7), 272-278.

Vilenius - Tuohimaa, P. M., Aunola, K., \& Nurmi, J. E. (2008). The association between mathematical word problems and reading comprehension. Educational Psychology, 28(4), 409-426. https://doi.org/10.1080/01443410701708228

Wildemuth, B. M. (Ed.). (2016). Applications of social research methods to questions in information and library science. California: ABC-CLIO.

Wu, H. J. (2011). Anxiety and reading comprehension performance in English as a foreign language. Asian EFL Journal, 13(2), 273-307.

Yoshida, M. (2012). The interplay of processing task, text type, and proficiency in L2 reading. Reading in a Foreign Language, 24(1), 1-29.

Zhang, D. (2012). Vocabulary and grammar knowledge in second language reading comprehension: A structural equation modeling study. The Modern Language Journal, 96(4), 558-575. https://doi.org/10.1111/j.1540-4781.2012.01398.x

Zhang, Y., \& Shanshan, H. (2011). Background Knowledge and reading comprehension. In International Conference on Computer Technology and Development, 3rd (ICCTD 2011). ASME Press. https://doi.org/10.1115/1.859919.paper333

\section{Copyrights}

Copyright for this article is retained by the author, with first publication rights granted to the journal.

This is an open-access article distributed under the terms and conditions of the Creative Commons Attribution license (http://creativecommons.org/licenses/by/4.0/). 